\title{
Modelling growth and reproduction of the Pacific oyster Crassostrea gigas: Advances in the oyster-DEB model through application to a coastal pond
}

\author{
Y. Bourlès ${ }^{a, b}$, M. Alunno-Brusciaa ${ }^{a, b, ~}{ }^{*}$, S. Pouvreau ${ }^{a}$, G. Tollu ${ }^{b}$, D. Leguay ${ }^{b, c}, C$. Arnaud ${ }^{b, c}$, P. \\ Goulletquer $^{d}$ and S.A.L.M. Kooijman ${ }^{\mathrm{e}}$
}

\footnotetext{
a Ifremer Station Expérimentale d'Argenton, 11 Presqu'île du Vivier, 29840 Argenton-en-Landunvez, France

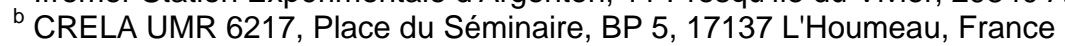

c UMS-ELA Place Gaby Coll et Allée Hubert Curien BP 5, 17137 L'Houmeau, France

d Ifremer Nantes, rue de l'lle d'Yeu, BP 21105, 44311 Nantes Cedex 03, France

e $V$ rije Universiteit, Faculty of Earth and Life Sciences, Department of Theoretical Biology, de Boelelaan 1085 , 1081 HV Amsterdam, The Netherlands
}

\author{
*: Corresponding author: M. Alunno-Bruscia, Tel.: +33 2988953 93; fax: +33 2988953 77, email address : \\ Marianne.Alunno.Bruscia@ifremer.fr
}

\begin{abstract}
:
A bio-energetic model, based on the DEB theory exists for the Pacific oyster Crassostrea gigas. Pouvreau et al. [Pouvreau, S., Bourles, Y., Lefebvre, S., Gangnery, A., Alunno-Bruscia, M., 2006. Application of a dynamic energy budget model to the Pacific oyster, C. gigas, reared under various environmental conditions. J. Sea Res. 56, 156-167.] successfully applied this model to oysters reared in three environments with no tide and low turbidity, using chlorophyll a concentration as food quantifier. However, the robustness of the oyster-DEB model needs to be validated in varying environments where different food quantifiers reflect the food available for oysters, as is the case in estuaries and most coastal ecosystems. We therefore tested the oyster-DEB model on C. gigas reared in an Atlantic coastal pond from January 2006 to January 2007. The model relies on two forcing variables: seawater temperature and food density monitored through various food quantifiers. Based on the high temperature range measured in this oyster pond $\left(3-30^{\circ} \mathrm{C}\right)$, new boundary values of the temperature tolerance range were estimated both for ingestion and respiration rates. Several food quantifiers were then tested to select the most suitable for explaining the observed growth and reproduction of $C$. gigas reared in an oyster pond. These were: particulate organic matter and carbon, chlorophyll a concentration and phytoplankton enumeration (expressed in cell number per litre or in cumulative cell biovolume). We conclude that when phytoplankton enumeration was used as food quantifier, the new version of oyster-DEB model presented here reproduced the growth and reproduction of $C$. gigas very accurately. The next step will be to validate the model under contrasting coastal environmental conditions so as to confirm the accuracy of phytoplankton enumeration as a way of representing the available food that sustains oyster growth.
\end{abstract}

Keywords: DEB theory; Modelling; Bivalves; Crassostrea gigas; Food Quantifiers; Temperature Effect; Coastal Environment 


\section{Introduction}

Energetic budget models have been widely applied to bivalves in aquaculture, especially for assessing the carrying capacity of coastal systems (e.g. [Héral, 1993], [Dowd, 1997], [Bacher et al., 1998], [Duarte et al., 2003] and [Grant et al., 2003]). Such models are based on ecophysiological modelling that details the physiological processes and energetics of an organism in response to environmental fluctuations. Most energetic models of bivalves are net production models (e.g. [Ross and Nisbet, 1990], [Raillard et al., 1993], [Smaal and Widdows, 1994], [Barillé et al., 1997], [Campbell and Newell, 1998], [Grant and Bacher, 1998], [Scholten and Smaal, 1998], [Ren and Ross, 2001], [Hawkins et al., 2002] and [Gangnery et al., 2003]) based on the Scope for Growth (SFG) concept (Bayne and Newell, 1983). Dynamic energy budget (DEB) models are a different type of energetic model that describes the rates at which organisms assimilate and utilise energy for maintenance, growth and reproduction. DEB modelling has also been applied to various bivalves (e.g. [Van Haren and Kooijman, 1993], [Ren and Ross, 2005], [Cardoso et al., 2006] and [Pouvreau et al., 2006]). The DEB theory is based on physical and chemical assumptions for individual energetics ([Kooijman, 1986] and [Kooijman, 2000]), whereas the energetics in SFG models are empirically-based using allometric relationships ([Lika and Nisbet, 2000], [Nisbet et al., 2000] and [Van der Meer, 2006]).

DEB theory has recently been more specifically applied to the Pacific oyster Crassostrea gigas (e.g. Van der Veer and Alunno-Bruscia, 2006 H.W. Van der Veer and M. AlunnoBruscia, The DEBIB project: dynamic energy budgets in bivalves, J. Sea Res. 56 (2006), pp. 81-84. Article | PDF (91 K) | View Record in Scopus | Cited By in Scopus (1)Van der Veer and Alunno-Bruscia, 2006). Pouvreau et al. (2006) validated the DEB model for this species reared in various different environments and concluded that the model could be applied in many ecosystems where $C$. gigas is cultured. Our study aims to refine the initial version of the oyster-DEB model by Pouvreau et al. (2006) and to test the updated version under new environmental conditions in an Atlantic oyster pond. More precisely, this paper describes how effects of temperature on physiological processes have been modified and improved in the model, compared with the extended Arrhenius 


\section{Introduction}

Energetic budget models have been widely applied to bivalves in aquaculture, especially for assessing the carrying capacity of coastal systems (e.g. [Héral, 1993], [Dowd, 1997], [Bacher et al., 1998], [Duarte et al., 2003] and [Grant et al., 2003]). Such models are based on ecophysiological modelling that details the physiological processes and energetics of an organism in response to environmental fluctuations. Most energetic models of bivalves are net production models (e.g. [Ross and Nisbet, 1990], [Raillard et al., 1993], [Smaal and Widdows, 1994], [Barillé et al., 1997], [Campbell and Newell, 1998], [Grant and Bacher, 1998], [Scholten and Smaal, 1998], [Ren and Ross, 2001], [Hawkins et al., 2002] and [Gangnery et al., 2003]) based on the Scope for Growth (SFG) concept (Bayne and Newell, 1983). Dynamic energy budget (DEB) models are a different type of energetic model that describes the rates at which organisms assimilate and utilise energy for maintenance, growth and reproduction. DEB modelling has also been applied to various bivalves (e.g. [Van Haren and Kooijman, 1993], [Ren and Ross, 2005], [Cardoso et al., 2006] and [Pouvreau et al., 2006]). The DEB theory is based on physical and chemical assumptions for individual energetics ([Kooijman, 1986] and [Kooijman, 2000]), whereas the energetics in SFG models are empirically-based using allometric relationships ([Lika and Nisbet, 2000], [Nisbet et al., 2000] and [Van der Meer, 2006]).

DEB theory has recently been more specifically applied to the Pacific oyster Crassostrea gigas (e.g. Van der Veer and Alunno-Bruscia, 2006 H.W. Van der Veer and M. AlunnoBruscia, The DEBIB project: dynamic energy budgets in bivalves, J. Sea Res. 56 (2006), pp. 81-84. Article | PDF (91 K) | View Record in Scopus | Cited By in Scopus (1)Van der Veer and Alunno-Bruscia, 2006). Pouvreau et al. (2006) validated the DEB model for this species reared in various different environments and concluded that the model could be applied in many ecosystems where C. gigas is cultured. Our study aims to refine the initial version of the oyster-DEB model by Pouvreau et al. (2006) and to test the updated version under new environmental conditions in an Atlantic oyster pond. More precisely, this paper describes how effects of temperature on physiological processes have been modified and improved in the model, compared with the extended Arrhenius 
1 relationship proposed by Van der Veer et al. (2006). Model simulations were performed using

2 a number of food quantifiers to identify those most suitable for predicting the growth of $C$.

3 gigas. In the initial oyster-DEB model by Pouvreau et al. (2006), chlorophyll $a$ concentration

4 (chl-a) was the only food quantifier tested. Although chl-a is often used to estimate the phytoplankton biomass available for filter-feeders, there are many sources of discrepancies when using chl-a: (1) quantity of chl-a per phytoplankton cell varies a great deal over the year (Llewellyn et al., 2005), (2) the chl-a measured includes inputs from many sources, e.g. from macroalgae and river detritic particles containing both labile and refractory components, toxic algae, and picoplankton such as Chlorophyta flagellates, which are not retained or assimilated by $C$. gigas (Barillé et al., 1993, Dupuy et al., 2000b). Moreover, chl-a is a photosynthetic pigment and not a nutritive compound for filter-feeders. We therefore tested additional food quantifiers: particulate organic matter (POM), particulate organic carbon (POC) and, for the first time to our knowledge, phytoplankton enumeration expressed both in cell number per litre and in cumulative biovolume of cells. This assessment aimed to determine the most relevant quantifier to explain oyster growth and reproduction throughout the year.

\section{Material and methods}

\subsection{Model description}

A detailed description of the DEB model validated for C. gigas is given in Pouvreau et al. (2006). The general framework of the oyster DEB model, i.e. the equations and most of the DEB parameters, was kept similar in the present study and hence only a brief summary of the main outline is presented here. The present study, however, focuses on new improvements concerning the temperature effect on oyster physiology and the choice of the most relevant food quantifier.

\subsubsection{Model design}

The DEB model assumes that the energy which is assimilated through ingested food is first stored in a reserve compartment. A fixed fraction $\kappa$ of the energy flux from reserves is then used for growth and somatic maintenance (plus heating in endothermic animals), with a priority for maintenance. The remaining energy fraction $(1-\kappa)$ is spent on maturity maintenance and maturation in embryos and juveniles or reproduction, i.e. gamete production and spawning, in adults. DEB parameter values are taken from Pouvreau et al. (2006) (Table 
1 1). Notation and symbols follow Kooijman (2000). Quantities are expressed per unit of 2 structural volume with square brackets [], or per unit of surface-area of the structural body 3 volume with braces \{\} . All rates have dots, indicating the dimension per time.

4 The energy ingestion rate $\dot{p}_{x}$ is proportional to the surface area of the structural body 5 volume $V^{2 / 3}$ and depends upon food density $X$ in the environment by a Holling type II 6 functional response:

$7 \quad \dot{p}_{X}=\left\{\dot{p}_{X m}\right\} f V^{2 / 3}$, with $f=\frac{X}{X+X_{K}}$ $\left(\mathrm{J} \mathrm{d}^{-1}\right)$

8 where $\left\{\dot{p}_{X m}\right\}$ is the maximum ingestion rate per unit of surface area and $f$ is the dimensionless

9 functional response which can vary between 0 and $1 . X_{K}$ is the saturation coefficient, or 10 Michaelis-Menten constant. It is the food density at which the ingestion rate is half the 11 maximum. The assimilation rate $\dot{p}_{A}$ is given as:

$12 \dot{p}_{A}=\left\{\dot{p}_{A m}\right\} f V^{2 / 3}$

13 where $\left\{\dot{p}_{A m}\right\}$ is the maximum surface-area-specific assimilation rate. Its precise value 14 depends on the oyster diet. The ratio $\left\{\dot{p}_{A m}\right\} /\left\{\dot{p}_{X m}\right\}$ gives the conversion efficiency of ingested 15 food into assimilated energy, known as the assimilation efficiency $A E$ called $\kappa_{A}$ in the DEB 16 theory.

17 Assimilation rate $\dot{p}_{A}$ contributes to the energy reserve dynamics given by:

$$
\frac{d E}{d t}=\dot{p}_{A}-\dot{p}_{C}
$$

where $\dot{p}_{C}$ is the utilisation rate of the reserve energy.

The kappa rule $(\kappa)$ states that a fixed fraction of $\dot{p}_{C}$ is allocated to somatic maintenance and growth. Maintenance rate $\dot{p}_{M}$ is proportional to the structural volume $V$, so $\dot{p}_{M}=\left[\dot{p}_{M}\right] . V$, with $\left[\dot{p}_{M}\right]$ the maintenance cost per unit of volume. Therefore, the structural body volume $V$ changes as: where $\left[E_{G}\right]$ denotes the volume-specific costs for structure. Kooijman (2000, chapter 3.4) showed that $\dot{p}_{C}$, the energy consumed (fixed and dissipated) by the body tissues, can be written as: 
1 where $[E]$ represents the energy density and equals $E / V$, and $\left[E_{m}\right]$ is the maximum energy

2 density in the reserve compartment. Thus, $[E]$ can vary between 0 and $\left[E_{m}\right]$.

As $\kappa$ is the fraction of the energy utilisation rate $\dot{p}_{C}$ spent on somatic maintenance plus growth, the remaining $(1-\kappa) \dot{p}_{c}$ is allocated to maturity maintenance and maturity in embryos and juveniles, or reproduction (i.e. gamete production and spawning) in adults. If the somatic and maturity maintenance rate coefficients are equal, the maturity maintenance $\dot{p}_{J}$ is proportional to the structure $V$ until juveniles reach sexual maturity at volume $V_{P}$. Maturity maintenance does not increase beyond this level. Thus, $\dot{p}_{J}$ is defined as:

$9 \quad \dot{p}_{J}=\left(\frac{1-\kappa}{\kappa}\right) \operatorname{Min}\left(V, V_{P}\right)\left[\dot{p}_{M}\right]$ $\left(\mathrm{J} \mathrm{d}^{-1}\right)$

The dynamics for energy allocated first to maturation in juveniles, and then to the 11 reproduction buffer $E_{R}$ in adults are:

$\frac{d E_{R}}{d t}=(1-\kappa) \dot{p}_{C}-\dot{p}_{J}$

13 Shell length $L(\mathrm{~cm})$ is proportional to the structural body volume $V$ :

$14 \quad L=\frac{V^{1 / 3}}{\delta_{m}}$

where $\delta_{m}$ is the dimensionless shape coefficient, estimated at 0.175 by Van der Veer et al. (2006), Pouvreau et al.(2006) and Bacher and Gangnery (2006) who each used independent datasets.

\subsubsection{Temperature effect (the Arrhenius relationship)}

Physiological processes, e.g. assimilation, maintenance and structural growth in the DEB model, depend on the body temperature. Within a species-specific temperature tolerance range, physiological rates increase exponentially with temperature, as described by the Arrhenius relation:

$\dot{k}(T)=\dot{k}_{1} \cdot \exp \left\{\frac{T_{A}}{T_{1}}-\frac{T_{A}}{T}\right\}$

where $\dot{k}(T)$ is a physiological rate at ambient temperature $T$ (in $\mathrm{K}), \dot{k}_{1}$ is its value at a chosen reference temperature $T_{1}$, and $T_{A}$ is the Arrhenius temperature (in $\mathrm{K}$ ) similar for all physiological rates of an animal. The basic Arrhenius correction $\exp \left\{\frac{T_{A}}{T_{1}}-\frac{T_{A}}{T}\right\}$ is applied in the description of temperature effect on physiological processes, giving 1 when $T=T_{1}$. For $C$. gigas, $T_{1}$ is commonly given at $20^{\circ} \mathrm{C}$. Outside the optimal temperature boundaries defined as 
$1 \quad T_{L}$ (lower boundary) and $T_{H}$ (upper boundary), i.e. at both low $\left(T<T_{L}\right)$ and high $\left(T>T_{H}\right)$ 2 temperatures, physiological rates drop quickly (Fig. 1). In the DEB theory, $T_{L}$ and $T_{H}$ are assumed to be the same for all physiological rates. To take into account both boundaries, equation (9) can be re-written with the extensive Arrhenius relationship:

$$
\dot{k}(T)=\dot{k_{1}} . \exp \left\{\frac{T_{A}}{T_{1}}-\frac{T_{A}}{T}\right\} .\left(1+\exp \left\{\frac{T_{A L}}{T}-\frac{T_{A L}}{T_{L}}\right\}+\exp \left\{\frac{T_{A H}}{T_{H}}-\frac{T_{A H}}{T}\right\}\right)
$$

where $T_{A L}$ and $T_{A H}$ are the Arrhenius temperatures (in $\mathrm{K}$ ) for the rate of decrease at each boundary. For $C$. gigas, $T_{L}$ and $T_{H}$ were respectively estimated at $8^{\circ} \mathrm{C}$ and $32^{\circ} \mathrm{C}$ (Van der Veer et al., 2006).

Values of the temperature tolerance range boundaries $T_{L}$ and $T_{H}$ were changed in this study relative to the initial oyster DEB model (Pouvreau et al., 2006). Two main reasons account for this modification. Firstly, the model was previously tested for a temperature range from 8 to $25^{\circ} \mathrm{C}$ (Pouvreau et al., 2006). In many coastal culture sites, such as oyster ponds, the seawater temperature can reach extreme values during winter or summer. In our experimental oyster pond, seawater temperature varied between 3 and $30^{\circ} \mathrm{C}$ (see results). Secondly, the DEB theory states that within the temperature tolerance range, physiological processes are affected in the same way by temperature, i.e. that $T_{L}$ and $T_{H}$ are assumed to be equal for all physiological rates (Kooijman, 2000). However, several studies have shown differences in temperature effect on feeding processes and respiration rate above a temperature threshold (e.g. Le Gall and Raillard, 1988; Bougrier et al., 1995; Ren et al., 2000, Hawkins et al., 2002, Mao et al., 2006; Le Moullac 2008). Le Gall and Raillard (1988) showed a negative effect of high temperature $\left(>25^{\circ} \mathrm{C}\right)$ on $C$. gigas growth rate. They explained this depression by a change of temperature effect between energy acquisition (food ingestion) which decreased significantly at temperatures above $25^{\circ} \mathrm{C}$, and energy allocation (metabolism and/or maintenance), illustrated by increasing respiration rate above $30^{\circ} \mathrm{C}$. Based on physiological measurements in acclimated individuals of $C$. gigas over a range of temperature between 5$30^{\circ} \mathrm{C}$, Bougrier et al (1995) reported increasing oxygen consumption rate from 5 to $30^{\circ} \mathrm{C}$ and increasing clearance rate (food consumption) up to a maximum of $19^{\circ} \mathrm{C}$-beyond which the clearance rate decreased. Similarly, Ren et al. (2000) modelled the clearance rate of $C$. gigas as a hyperbolic function of temperature, with a maximum value at $25^{\circ} \mathrm{C}$ (like the threshold value in Le Gall and Raillard, 1988), whereas oxygen consumption rate increased exponentially with temperature. Thus, we assumed that for temperatures above $25^{\circ} \mathrm{C}$, oysters in our experimental pond neither fed (no assimilation) nor allocated energy to growth and maturity. Under this particular condition, respiration could correspond to somatic and 
1 maturity maintenance. We thus proposed two new extensive Arrhenius corrections (Fig. 1)

2 with $T_{L}=3^{\circ} \mathrm{C}$ for both ingestion and respiration rates, and with $T_{H \text { ing }}=25^{\circ} \mathrm{C}$ and $T_{H \text { resp }}=$ $332^{\circ} \mathrm{C}$, respectively for ingestion and respiration rates. Though temperature $>25^{\circ} \mathrm{C}$ affected

4 differently ingestion $v s$ respiration rates, the Arrhenius temperature $T_{A}$ remained the same for 5 all physiological rates.

\subsubsection{Food quantifiers}

The half saturation coefficient $X_{K}$ was the only free-fitted parameter of the oyster-DEB model, as it is supposed to vary according to food quality (Kooijman, 2006), and therefore according to shellfish growing area. The initial version of the oyster-DEB model used chlorophyll $a$ concentration (chl-a) to quantify the trophic resources. In our study, several more food quantifiers were tested to identify the most suitable one to quantitatively describe C. gigas growth and reproduction. The food quantifiers tested were: chl-a, particulate organic matter (POM) and carbon (POC), and phytoplankton enumeration expressed in cell number per litre or in cumulative cell biovolume.

\subsection{Environmental and biological data}

\subsubsection{Study area}

The experimental site 'Marais du Plomb' is located in the northern part of MarennesOléron Bay (Fig. 2.A). It consists of a series of ponds communicating with the sea by small channels (Fig. 2.B); no renewal of seawater in the pond occurs for a few days at neap tide. The ponds are $1 \mathrm{~m}$ deep and $200 \mathrm{~m}^{2}$ in area. Oysters were placed in oyster bags attached to racks at mid-depth.

\subsubsection{Forcing variables}

Hydro-biological parameters were monitored in two complementary ways. Temperature $\left({ }^{\circ} \mathrm{C}\right)$ and chlorophyll $a$ concentration (chl-a in $\mu \mathrm{g} \mathrm{L}^{-1}$ ) were recorded every 30 min with a continuous recording multi-parameter detector (DataSonde OTT Hydrolab DS_5X) immersed in the vicinity of the oyster racks $(1.2 \mathrm{~m})$. Seawater samples were also collected once a week to quantify particulate organic (POM) and inorganic (PIM) matter, and particulate organic carbon (POC) and to make phytoplankton identification and enumeration. Samples of seston for POM, PIM and POC determination were analysed as described in Aminot et al. (2004). 
Identification and enumeration of phytoplankton species (or groups when identification was not possible to the species level, e.g. Euglenophyceae, Pleurosigma+Gyrosigma spp.) were done on weekly seawater samples fixed with Lugol's solution ( $4 \mathrm{~mL}$ in $1 \mathrm{~L}$ sample). Size and volume of each species or group were estimated by microscopic analysis, according to Guillocheau (1988). The phytoplankton Tetraselmis spp and Kryptoperidium foliaceum, which showed high blooms and which were respectively reported in the literature as having a low food value (Robert et al., 2002) and some potentially toxic effects on bivalves (Landsberg, 2002), were excluded from phytoplankton enumeration to test the model.

\subsubsection{Data validation}

Five hundred 2-y old oysters were randomly sampled in a large population originating from Marennes-Oléron Bay. They were deployed in an experimental oyster pond (Fig. 2.B) in January 2006. Oyster growth was assessed through biometric measurements on 30 oysters randomly collected on a monthly basis, and every two weeks from June to August, to identify and quantify spawning events. Oyster dry flesh mass (DFM) was obtained after a 72-hour freeze-drying cycle and determined to the nearest $0.001 \mathrm{~g}$ (Sartorius electronic balance, precision 0.0001).

\subsection{Model simulations}

The model was run on STELLA® 8.0 software, using the model parameters from Pouvreau et al. (2006) and the new boundaries for the temperature tolerance range. The halfsaturation coefficient $X k$ was free-fitted for each food quantifier. The coefficients for conversion of oyster biological components to state variables and processes were taken from Pouvreau et al. (2006). The initial values of the state variables were as follows: energy in Structure $E_{V}$ was 5000 Joules, energy in Storage $E$ was $2000 \mathrm{~J}$ and energy in the reproduction buffer $E_{R}$ was $2500 \mathrm{~J}$. The structural volume $V$ was calculated according to length $L$, using the shape coefficient $\delta$ and the formula $V=(\delta . L)^{3}$, as in Pouvreau et al. (2006). The initial value of Storage $E$ and the reproduction buffer $E_{R}$ were deduced to obtain the correct initial total dry mass $(0.56 \mathrm{~g})$, as well as realistic initial values for the energy density [E] and gonado-somatic index GI defined as the ratio between the gonad mass and the total flesh mass (i.e. structure, plus reserve and gonad). Since the temperature effect had been shown to be obviously different for ingestion and respiration rates, different boundary values of the temperature tolerance range were applied for each physiological process. 
The forcing variables used to run the model were the seawater temperature and food density expressed by the different food quantifiers. Phytoplankton enumeration, expressed in cell number per litre or in cumulative cell biovolume, was tested as a food quantifier in two ways: $1 /$ with the total phytoplankton composition identified and $2 /$ with only the "selected" phytoplankton composition, without the two excluded species (see 2.2.2.).

Individual growth expressed in dry flesh mass (DFM) was simulated by the model with each food quantifier and then compared to observed DFM data. For each simulation, the goodness of fit of the model was estimated by fitting a linear regression between observed and simulated values, and comparing the resulting slopes and intercept of significant regressions to 1 and 0 , respectively.

\section{Results}

\subsection{Forcing variables}

Temporal variations in the forcing variables between January 2006 and January 2007 are illustrated in Figures 3 and 4, for the seawater temperature and food quantifiers, respectively. Seawater temperature showed a classical seasonal pattern from $3^{\circ} \mathrm{C}$ to $30^{\circ} \mathrm{C}$ between January and July 2006 (Fig. 3). POC varied from $0.2 \mu \mathrm{g} \mathrm{L}^{-1}$ in February to $2.7 \mu \mathrm{g} \mathrm{L}^{-1}$ in May (Fig. 4.A). POM showed a similar pattern to POC, with concentration varying from $2 \mathrm{mg} \mathrm{L}^{-1}$ in February 2006 to $12 \mathrm{mg} \mathrm{L}^{-1}$ in January 2007 (Fig. 4.B). Chl-a varied between $1 \mu \mathrm{g} \mathrm{L}^{-1}$ in February and August and $25 \mu \mathrm{g} \mathrm{L}^{-1}$ during spring algal blooms in April (Fig. 4.C). These three food quantifiers exhibited only three common peaks (1, 2 and 3, Fig. 4) whereas most of their other peaks were obviously different in terms of magnitude and timing (e.g. peaks i to viii, Fig. 4).

The other food quantifier tested in the oyster-DEB model was phytoplankton enumeration (Fig. 4.D) expressed in cell number (cell $\left.\mathrm{L}^{-1}\right)$ and in cumulative cell volume $\left(\mu \mathrm{m}^{3} \mathrm{~L}^{-1}\right)$. The two expressions of phytoplankton enumeration presented different phytoplankton dynamics, except for peak 2, which had also been seen in the three first food quantifiers (Fig. 4). When expressed in number of cells per litre, the total phytoplankton exhibited four high blooms above $10^{6}$ cell $\mathrm{L}^{-1}$. The highest ones reached about $5 \cdot 10^{6}$ cell $\mathrm{L}^{-1}$ (September 6 th) and $3.7 \cdot 10^{6}$ cell $\mathrm{L}^{-1}$ (July 6th). Expressed in their biovolume, some phytoplanktonic blooms corresponded to those identified by enumeration (in early July and early September), but other blooms were revealed. Here, the highest blooms reached $16 \cdot 10^{9} \mu \mathrm{m}^{3} \mathrm{~L}^{-1}$ in late September and about $13 \cdot 10^{9} \mu \mathrm{m}^{3} \mathrm{~L}^{-1}$ in early July. The gap between blooms expressed in cell number or biovolume 
1 is explained by the size variability between species (Table 2.B). Phytoplanktonic cell 2 biovolume ranged from $500 \mu^{3}$ for Tetraselmis sp. to $600000 \mu \mathrm{m}^{3}$ for Flavella sp., i.e. interspecific cell size differences could vary by up to 1000 times.

More than 100 species or groups of phytoplankton cells were identified in the experimental oyster pond. Several species, present at low densities but all year long, showed a high frequency (e.g. Leptocylindrus sp., Achnantes sp., Amhora sp., Cocconeis sp., Oblea sp., Prorocentrum sp.). Despite the high diversity, only a few phytoplanktonic species contributed to the major part of the density observed through the year. Seven species/groups represented about $90 \%$ of the total cumulative enumeration (Table 2.A). Among them, Tetraselmis sp. and the Class Euglenophyceae contributed more than 47\%. In terms of biovolume, the ranking was different with a different set of seven species/groups representing about $83 \%$ of the total cumulative algal biovolume available over the year (Table 2.B). Among these, two species, Pleurosigma elongatum and Kryptoperidinium foliaceum, which had respective cell biovolume of $150000 \mu^{3}$ cell $^{-1}$ and $30000 \mu \mathrm{m}^{3}$ cell $^{-1}$, contributed about $53 \%$ of the total phytoplankton biovolume estimated over one year.

\subsection{Oyster growth}

The observed dry flesh mass (DFM) over the year showed two increasing periods, first between February and June, then from September to January (Fig. 5). In February, there was a slight decrease of the DFM from $0.75 \mathrm{~g}$ to $0.67 \mathrm{~g}$. An important increase of DFM then occurred in spring and the level reached $3.09 \mathrm{~g}$ in late June, probably due to gametogenesis. During summer a significant decrease was observed until August, with DFM dropping to 1.75 g, most likely due to two processes. Firstly, two spawning events occurred, a massive one in early July and a minor one in early August. Secondly, no growth was observed at this time. Oysters did not benefit from the apparently suitable food density level (high POC and POM, Fig. 4) in July because of the high temperature above $25^{\circ} \mathrm{C}$, which inhibited feeding processes (see 2.1.2.). In autumn, the DFM again showed a significant increase, reaching more than $3 \mathrm{~g}$ by January 2007.

\subsection{Growth simulations}

The growth of dry flesh mass (DFM) was simulated with the updated version of the oyster-DEB model, including the improvements incorporated for temperature effects on physiological processes. For each food quantifier tested, the model was adjusted for the half saturation coefficient $X_{K}$ only as this parameter is diet-specific. The first three food 
1 quantifiers, chl-a, POC and POM, commonly used in bivalve nutrition studies, provided the 2 same simulation pattern, which had no optimal agreement with the observed growth (Fig. 5; 3 Table 3). These simulations underestimated the observed dry flesh mass in spring and summer, and over-estimated it for the following winter. The optimised values for $X_{K}$ were 9 $\mu \mathrm{g} \mathrm{L}{ }^{-1}, 1.3 \mu \mathrm{g} \mathrm{L}^{-1}$ and $6.4 \mathrm{mg} \mathrm{L}^{-1}$, for chl-a, POC and POM respectively.

Phytoplankton enumeration was used as a food quantifier in cell number per litre and in cumulative cell biovolume, first with the total composition identified throughout the year, and then with the selected phytoplankton composition only (see 2.1.3). When using the selected phytoplankton (S-phyto) expressed in cell number, both the magnitude and shape of the simulated DFM growth trajectories fitted quite well the observed growth (Fig. 6A). Compared to total phytoplankton composition (Figs. 6C \& 6D), S-phyto in cell number led to the best fit of the regression model between observed and simulated DFM with slope and intercept which were not significantly different from $1(p$-value $=0.940)$ and $0(p$-value $=0.991)$ respectively (Table 3). In contrast, the selected phytoplankton expressed in cell biovolume provided the same simulation pattern as the first three food quantifiers, with a dry flesh mass underestimated in spring and summer, and over-estimated in the following winter. $X_{K}$ values were $1.6 \cdot 10^{5}$ cell $\mathrm{L}^{-1}$ and $1.4 \cdot 10^{9} \mu \mathrm{m}^{3} \mathrm{~L}^{-1}$, for phytoplankton enumeration expressed in cell number and biovolume respectively (Fig. 6B).

\section{Discussion}

In this study, several parameters of the existing oyster-DEB model developed by Pouvreau et al. (2006) were reconsidered and modified. The resulting second version of the model was then applied and validated on a new dataset of environmental and growth variables. The model was run with different food quantifiers, and phytoplankton enumeration demonstrated its reliability to represent the best the available food explaining observed oyster growth. We first discuss the food quantifier assessment, then analyse the design of the oyster-DEB model to explain how environmental parameters affect oyster physiology.

\subsection{Food quantifier assessment}

The half-saturation coefficient $X_{K}$, which describes food ingestion through the functional response $f$, was useful for making a methodical examination of the food quantifiers to 31 highlight which could best quantitatively explain the growth pattern observed over the year. $X_{K}$ was the only free-fitted parameter for each food quantifier tested, as it was diet-specific. 
1 The optimal value for chlorophyll $a$ concentration (chl-a) was $8 \mu \mathrm{g} \mathrm{L}^{-1}$, in accordance with

2 Pouvreau et al. (2006) $X_{K}$ values, which varied from 3 to $17 \mu \mathrm{g} \mathrm{L}^{-1} . X_{K}$ values for the selected 3 phytoplankton enumeration were $1.6 \cdot 10^{5}$ cell $\mathrm{L}^{-1}$ and $1.4 \cdot 10^{9} \mu \mathrm{m}^{3} \mathrm{~L}^{-1}$ in cell number and in 4 cumulative cell biovolume respectively. To our knowledge, this is the first time that a halfsaturation coefficient $X_{K}$ has been given for oysters fed with natural phytoplankton enumerated from direct microscopy analyses.

The two species removed from the total phytoplankton enumeration were among the most abundant species whether phytoplankton enumeration was expressed in cell number per litre (Tetraselmis sp.) or in cumulative algal biovolume (Kryptoperidinium foliaceum). The selected phytoplankton data provided a better goodness of fit between observed and simulated oyster growth than did the total phytoplankton enumeration (Fig. 6, Table 3). It demonstrated that the two species taken out of the total phytoplankton composition were not a significant part of the phytoplankton sustaining observed oyster growth, although they were among the most abundant phytoplankton species. A recent experiment consisting in measuring growth of C. gigas juveniles fed on Tetraselmis suecica (monospecific diet) over seven weeks under controlled conditions showed that oyster ingestion for T. suecica was very low and absorption efficiency almost null, and that no growth in terms of dry flesh mass occurred during the experiment (Boglino 2008). In further studies on oyster food availability, the phytoplankton composition and species dynamics should be analysed and tested with the updated oysterDEB model to determine the phytoplankton species that quantitatively contribute to oyster energetics.

Our results showed that selected phytoplankton enumeration in cell number per litre better represented the available food for oysters than did the same phytoplankton expressed in cumulative cell biovolume. This result could be explained by the dynamics of phytoplankton composition, dominated in spring by diatoms and in autumn by large dinoflagellates. Large dinoflagellates are known to be of poor food quality for bivalves (Landsberg, 2002) and many taxa are even potentially toxic (e.g. Gymnodiniaceae, Dinophyceae). The use of phytoplankton enumeration expressed in volume over-estimated the contribution of large dinoflagellates to the available food sustaining oyster energetics, compared with the major contribution by diatoms. In contrast, phytoplankton enumeration expressed in cell number per litre was more influenced by the numerous diatoms identified in the oyster pond. Moreover, cell volume calculation from cell size and shape could increase inaccuracy of cumulative phytoplanktonic volume estimates. 
1 Cell volume and phytoplankton carbon content relationships have been widely studied 2 (e.g. Strathmann, 1967; Montagnes et al., 1994; Menden-Deuer and Lessard, 2000; Cornet3 Barthaux et al., 2007). However, the allometric equations in these previous works were 4 proposed for broad phytoplanktonic groups. Menden-Deuer and Lessard (2000) gave different $\mathrm{C}$ :volume relationships for diatoms, dinoflagellates and other protist phytoplankton, leading to global equations that incorporated many uncertainties in phytoplankton carbon estimation. In coastal ecosystems dominated by a small number of algal blooms $(<10$ during the year), such as the pond ecosystem of our study, specific equations established from species identification and direct measures (by particle counter for instance) would probably be more powerful than the previously published general equations relying on estimated volume from cell size and shape for wide phytoplanktonic groups (diatoms or dinoflagellates). Furthermore, phytoplankton carbon content evaluation requires extensive environmental analysis and would therefore not be an easy food quantifier to measure for a model designed for simple use in diverse environments.

Chlorophyll a concentration (chl-a) has commonly been used to represent either phytoplankton biomass or the food filtered and digested by bivalves. Recently, Ren and Schiel (2008) proposed a DEB model specifically designed for $C$. gigas reared in New Zealand waters, which they validated on chl-a data. However, the usefulness of chl-a has been questioned in many studies (e.g. Llewellyn et al., 2005; Ren and Ross, 2005; Pouvreau et al., 2006). In our study, chl-a, POC, POM and phytoplankton enumeration were measured. As reported above, chl-a variations were very different from those of phytoplankton enumeration. Each food quantifier was tested independently. The first three food quantifiers presented the same pattern through the year (Fig. 4) and produced the same simulations (Fig. 5) with an underestimation of the dry flesh mass during summer and an overestimation the next winter. These environmental parameters did not provide good simulations of oyster growth dynamics. In contrast, the two direct indicators of selected phytoplankton biomass, i.e. phytoplankton enumeration expressed in cell number and in cumulative cell biovolume, provided reasonable agreements between observed and simulated dry flesh mass (Table 3). These indicators confirmed that $C$. gigas fed and grew on the available phytoplankton biomass, which was not well represented by chl-a throughout the year under the environmental conditions of our study. The DEB model designed for $C$. gigas in New Zealand by Ren and Schiel (2008) was successfully validated on chl-a data because the environmental conditions of their study differed from those in other ecosystems. Seawater temperature, chl-a and seston concentration (TPM) are lower in the New Zealand Sounds, with a smaller range of variation compared with 
1 environmental conditions found on French coasts (Ren et al., 2000). Under these specific 2 conditions, chl-a is a reliable indicator of the phytoplankton available for oysters.

Although food quantifiers were tested independently, environmental parameters can affect more than one simultaneously, e.g. the total particulate matter (TPM) influences the clearance rate and thus the food ingestion. For further development of the oyster-DEB model, feeding processes should be defined more precisely but without making the model too complex, i.e. by limiting the number of parameters to describe the food acquisition processes (see 4.2. p. 16). As a complementary approach of describing with more details food acquisition in DEB model, we would recommend to define and test new food quantifiers, e.g. the chl-a:C ratio proposed by Cloern et al. (1995) (see Grangeré et al. 2009 -this issue), which may represent accurately the food ingested by $C$. gigas. Similarly, a half-saturation coefficient which value would vary over seasons could improve the accuracy of the food quantifier because seawater composition is closely related to season; like the sources of chl-a and the dynamics of phytoplankton composition in the pond ecosystem, dominated by diatoms in spring and by dinoflagellates in autumn. Finally, using a multivariate functional response as a way to integrate several food sources is likely a promising approach (Kooijman 2000, p. 160).

According to the best simulation obtained, i.e. from selected phytoplankton enumeration, oyster growth dynamics can be described as follows: in February, no growth was observed due to the low phytoplankton biomass and temperature below $8^{\circ} \mathrm{C}$. From March to June, the high growth of dry flesh mass (DFM) was sustained by several blooms of diatoms and by increasing temperatures, which rose from $5^{\circ} \mathrm{C}$ to $25^{\circ} \mathrm{C}$. Summer seawater temperatures higher than $25^{\circ} \mathrm{C}$ in July affected the dynamics of oyster food uptake. This, in addition to the two spawning events, explained the decrease of DFM in July, which occurred despite a bloom of Euglenophyceae. In August, little phytoplankton was detected $\left(<10^{5}\right.$ cell $\left.\mathrm{L}^{-1}\right)$ implying no growth in DFM. In autumn, oyster growth was again observed. In September and October, the decreasing temperature (from $25^{\circ} \mathrm{C}$ to $15^{\circ} \mathrm{C}$ ) remained optimal to sustain an increase of dry flesh mass from $1.75 \mathrm{~g}$ to $2.65 \mathrm{~g}$ despite limited available phytoplankton. In contrast, temperatures were low (from $15^{\circ} \mathrm{C}$ to $5^{\circ} \mathrm{C}$ ) in November and December, but oyster growth was sustained by consistent phytoplankton blooms.

\subsection{Oyster-DEB model}

Some improvements were made to the oyster-DEB model in terms of 1) the effect of temperature on oyster physiology, 2) the spawning process and 3) the feeding process. First, the temperature effect on physiological processes was reassessed, with a fine distinction of the 
1 rules suggested in the DEB theory (Kooijman, 2000). The abundant literature on bivalve 2 physiology (e.g. Widdows, 1976; Le Gall and Raillard, 1988; Bougrier et al., 1995; Ren et al., 2000; Hawkins et al., 2002; Mao et al., 2006) underlines the negative effect of temperatures above $20-25^{\circ} \mathrm{C}$ on filtration rate, while showing that respiration continues to increase over $30^{\circ} \mathrm{C}$. The result for $C$. gigas is a decline in growth rate, or even a loss in weight above $25^{\circ} \mathrm{C}$, whatever the trophic resources. Respiration represents the overall level of metabolic processes, and at high temperature, respiration rate increase despite a fall of ingestion rate and so of energy acquisition. Then above $25^{\circ} \mathrm{C}$, we considered that respiration could correspond mainly to maintenance in non feeding (and non-growing) $C$. gigas, thus neglecting all other contributions (assimilation, overheads of growth and reproduction). The discrepancy between temperature effect on respiration and ingestion rates was integrated into the updated oysterDEB model. Thus, the upper boundaries $T_{H}$ of the Arrhenius correction relationship were $25^{\circ} \mathrm{C}$ and $32^{\circ} \mathrm{C}$ respectively for ingestion and maintenance rate. According to DEB assumptions, temperature affects equally all metabolic rates in the temperature tolerance range which is determined for oyster between $3{ }^{\circ} \mathrm{C}$ and $25^{\circ} \mathrm{C}$. The distinction made in the oyster-DEB model between energy uptake and use above $25^{\circ} \mathrm{C}$ illustrated the energetic deficiency of $C$. gigas in warm water. At the other limit of the temperature tolerance range, the lower boundary $T_{L}$ of the Arrhenius correction relationship was kept similar for the two functions, at $3^{\circ} \mathrm{C}$ : a lower value than the $8^{\circ} \mathrm{C}$ proposed by Van der Veer et al. (2006). The application of the new temperature tolerance range upper boundaries for ingestion and maintenance rates, representing the energy acquisition and energy expenditure respectively, resulted in a slowing down of oyster growth in July, which fits well with biological observations made at this time, i.e. no growth, plus the two spawning events. Preliminary simulations of the oyster dry flesh mass based on the temperature tolerance range used in Pouvreau et al. (2006) and on selected phytoplankton enumeration, showed an overestimation of DFM in early July (Bourlès, unpublished data). Our finding that temperature $>25^{\circ} \mathrm{C}$ affects ingestion differently from respiration has no consequence on oyster energetics in the temperature tolerance range between $3^{\circ} \mathrm{C}$ and $25^{\circ} \mathrm{C}$.

The two parameters controlling the spawning events were then also adjusted to allow several spawnings like those observed during the summer in the oyster pond. The temperature threshold and gonado-somatic index were free-fitted according to the condition index observed in reared oysters. They were respectively estimated at $22^{\circ} \mathrm{C}$ and $40 \%$, which are slightly higher than the values given by Pouvreau et al. (2006) in the first oyster-DEB model, $\left(20^{\circ} \mathrm{C}\right.$ and $\left.35 \%\right)$. This may be explained by the specific environmental quality of the oyster 
1 pond which showed high temperature variations and a relatively high food level. Recently,

2 Ren and Schiel (2008) pointed out that DEB parameter values must be influenced by specific environmental conditions even if they are supposedly species-specific. Ren and Schiel (2008) re-estimated the main DEB parameter values from specific experiments on C. gigas, but they validated their DEB model outside the reproductive period, thus avoiding the need to simulate spawning events. Although it appears difficult to integrate reproductive processes in a bioenergetic model, these need to be understood and quantified to include the triggering of spawning events according to given environmental conditions. It is a necessary step to estimate the quantitative energy budget of $C$. gigas through time, whatever its living environment, whether this is for aquaculture purposes or for the study of its widening natural distribution.

In our model, energy acquisition was only supported by food ingestion and assimilation. The model did not take into account the filtration and selection processes which are commonly integrated into most ecophysiological models (e.g. Bacher et al., 1991; Barillé et al., 1997; Campell and Newell, 1998; Grant and Bacher 1998; Powell et al., 1992; Raillard et al., 1993; Ross and Nisbet, 1990). The present model assumes a simple Type 2 functional response. Although total seston and inorganic particles obviously interfere in feeding processes (Grizzle et al., 2006; Ren et al., 2000), unpublished experimental data on oyster filtration and ingestion showed that the Type 2 functional response is appropriate for the Pacific oyster Crassostrea gigas. Moreover, energy acquisition in the oyster-DEB model was built on food quantifiers which represent the food available for oysters. Thus, we chose to maintain the simple use of the functional response that also has the advantage of involving few parameters. However, the general feeding model developed by Ren and Ross (2005) is probably suitable for all bivalve species, and could be investigated to further improve oyster feeding response to a variable environment. In the recent DEB model validated for $C$. gigas by Ren and Schiel (2008), the feeding processes were also simplified to the Type 2 functional response. However these authors also recommended that further refinements of the model should include the effect of food quantity and quality, i.e. the integration of supplementary environmental variables in addition to the two forcing variables involved in the oyster-DEB model presented here.

Assimilation efficiency was considered as a constant in the present model. Filter-feeders consume suspended particles composed of a mixture of detrital and phytoplankton organic matter containing both labile and refractory components. Studies have reported varying assimilation efficiency with seasonal variations of food quality and phytoplankton 
1 composition (Hawkins and Bayne, 1985; Hawkins et al., 1999). However, Ren et al. (2000)

2 found a constant absorption efficiency of $86 \%$ above approximately 5\% seston organic 3 content. Overall, ecophysiological models are usually built with a constant assimilation

4 efficiency. Ren and Ross $(2001,2005)$ and Van der Veer et al. (2006) reported an assimilation efficiency of $75 \%$ for various bivalves. Following unpublished experimental data and the first oyster-DEB model developed by Pouvreau et al. (2006), the same value was used in the present model.

\subsection{Conclusion}

The validation of the new oyster-DEB model demonstrates its suitability for simulating Crassostrea gigas growth and reproduction in rearing sites with broader temperature variations than the controlled conditions tested by Pouvreau et al. (2006). The updated oysterDEB model presented in this paper supports the "aim for generality" of this earlier paper. The second version of the oyster-DEB model now needs to be tested in different environments where $C$. gigas grows. Overall, our model has proved to be a useful tool for testing food quantifiers on a comparitive basis. Although several food sources have been identified for oyster feeding (e.g. Deslous-Paoli and Héral, 1984; Barillé et al., 1993; Dupuy et al., 2000a), it appears that phytoplankton expressed in cell number per litre explains the greater part of observed oyster growth. The oyster-DEB model could be used as a generic model to further study $C$. gigas physiology in response to environmental fluctuations (e.g. food selection processes according to food resource quality, and spawning events in relation to summer temperature and gonad development). The model should also be a powerful tool as part of a larger ecosystem model to assess carrying capacity of different areas where the Pacific oyster is cultured.

\section{Acknowledgements}

Y. Bourlès was supported by funding of Région Poitou-Charentes and Ifremer during his $\mathrm{PhD}$ project. We would like to thank two anonymous referees for their helpful comments on the manuscript. The members of the European Research Group AquaDEB (http://www.ifremer.fr/aquadeb/) are gratefully acknowledged for the stimulating discussions and useful comments. This paper benefited from helpful comments and English revision by 


\section{References}

3 Aminot, A., Kerouel, R., Bretaudeau, J., 2004. Marine ecosystem hydrology parameters and analyses. Méthodes Anal. Milieu Mar. 336 pp.

Bacher, C., Duarte, P., Ferreira, J.G., Héral, M., Raillard, O., 1998. Assessment and comparison of the Marennes-Oleron Bay (France) and Carlingford Lough (Ireland) carrying capacity with ecosystem models. Aquat. Ecol. 31, 379-394.

Bacher, C., Héral, M., Deslous-Paoli, J.M., Razet, D., 1991. Modèle énergétique uni-boite de la croissance des huîtres (Crassostrea gigas) dans le bassin de Marennes-Oléron. Can. J. Fish. Aquat. Sci. 48, 391-404.

Bacher, C., Gangnery, A., 2006. Use of dynamic energy budget and individual based models to simulate the dynamics of cultivated oyster populations. J. Sea Res. 56, 140-155.

Barillé, L., Prou, J., Héral, M., Bougrier, S., 1993. No influence of food quality, but rationdependent retention efficiencies in the Japanese oyster Crassostrea gigas. J. Exp. Mar. Biol. Ecol. 171, 91-106.

Barillé, L., Héral, M., Barillé-Boyer, A.L., 1997. Modélisation de l'écophysiologie de l'huître creuse Crassostrea gigas dans un environnement estuarien. Aquat. Living Resour. 10, 3148.

Bayne, B.L., Newell, R.C., 1983. Physiological energetics of marine molluscs. In: Saleuddin A.S.M. , Wilbur K.M. (Eds.), The Mollusca, vol. 4. Academic Press, London, pp.407-515.

Boglino, A. 2008. Les espèces phytoplanctoniques majeures des côtes atlantiques françaises sont-elles équivalentes pour l'ingestion et la croissance de l'huître creuse (Crassostrea gigas) ? Réponse par le biais d'une approche expérimentale. Master 2 report, Sciences de l’Univers Environnement Ecologie, Pierre \& Marie Curie University, Paris 6, 45 p.

Bougrier, S., Geairon, P., Deslous-Paoli, J.M., Bacher, C., Jonquières, G., 1995. Allometric relationships and effects of temperature on clearance and oxygen consumption rates of Crassostrea gigas (Thunberg). Aquaculture 134, 143-154.

Campbell, D.E., Newell, C.R., 1998. MUSMOD, a production model for bottom culture of the blue mussel Mytilus edulis. L. J. Exp. Mar. Biol. Ecol. 219, 171-203.

30 Cardoso, J.F.M.F., Van der Veer, H.W., Kooijman, S.A.L.M., 2006. Body size scaling relationships in bivalve species: A comparison of field data with predictions by the Dynamic Energy Budget (DEB) theory. J. Sea Res. 56: 125-139. 
1 Cloern, J.E., Grenz, C., Vidergar-Lucas, L., 1995. An empirical model of the phytoplankton chlorophyll:carbon ratio-the conversion factor between productivity and growth rate. Limn. Oceanogr. 40, 1313-1321.

Cornet-Barthaux, V., Armand, L., Quéguiner, B., 2007. Biovolume and biomass estimates of key diatoms in the Southern Ocean. Aquat Microb. Ecol. 48: 205-308.

Dowd, M., 1997. On predicting the growth of cultured bivalves. Ecol. Model. 104, 113-131.

Deslous-Poali, J.M., Héral, M., 1984. Transferts énergétiques entre l'huître Crassostrea gigas de 1 an et la nourriture potentielle disponible dans l'eau d'un bassin ostréicole. Haliotis 14, 79-90.

Deslous-Poali, J.M., Héral, M., 1988. Biochemical composition and energy value of Crassostrea gigas (Thunberg) cultured in the bay of Marennes-Oléron. Aquat. Living Resour. 1: 239-249.

Duarte, P., Meneses, R., Hawkins, A.J.S., Zhu, M., Fang, J., Grant, J., 2003. Mathematical modelling to assess the carrying capacity for multi-species culture within coastal waters. Ecol. Model. 168, 109-143.

Dupuy, C., Pastoureaud, A., Ryckaert, M., Sauriau, P.G., Montanié, H., 2000a. Impact of the oyster Crassostrea gigas on microbial community in Atlantic coastal ponds near La Rochelle. Aquat. Microbial Ecol. 22, 227-242.

Dupuy, C., Vaquer, A., Lam-Höai, T., Rougier, C., Mazouni, N., Lautier, J., Colloc, Y., Le Gall, S., 2000b. Feeding rate of the oyster Crassostrea gigas in a natural planktonic community of the Mediterranean Thau Lagoon. Mar. Ecol. Prog. Ser. 205, 171-184.

Grangeré, K., Ménesguen, A., Lefebvre, S., Bacher, C., Pouvreau, S. Modelling the influence of environmental factors on the physiological status of the Pacific oyster Crassostrea gigas in an estuarine embayment; The Baie des Veys (France). J. Sea Res. doi: SEARESD-08-00109R1 (this issue).

Gangnery, A., Chariband, J., Lagarde, F., Le Gall, P., Oheix, J., Bacher, C., Buestel, D., 2003. Growth model of the Pacific oyster Crassostrea gigas, cultured in Thau Lagoon (Méditerranée, France). Aquaculture 215, 267-290.

Grant, J., Bacher, C., 1998. Comparative models of mussel bioenergetics and their validation at field culture sites. J. Exp. Mar. Biol. Ecol. 219, 21-44.

Grant, J., Archambault, M., Bacher, C., Cranford, P., 2003. Integration of modelling and GIS in studies of carrying capacity for bivalve aquaculture. J. Shellfish Res. 22, 332. 
1 Grizzle, R.E., Green, J.K., Luckenbach, M.W., Coen, L.D., 2006. A new in situ method for

measuring seston uptake by suspension-feeding bivalve molluscs. J. Shellfish Res. 25, 643-649.

Guillocheau, N., 1988. Spatial and temporal distribution of Arcachon Basin phytoplankton. Ph.D thesis, University of Aix-Marseille, Marseille.

Hawkins, A.J.S., Bayne, B.L., 1985. Seasonal variation in the relative utilization of carbon and nitrogen by the mussel Mytlius edulis: budgets, conversion efficiencies and maintenance requirements. Mar. Ecol. Prog. Ser. 25, 181-188.

Hawkins, A.J.S., Duarte, P., Fang, J.G., Pascoe, P.L., Zhang, J.H., Zangh, X.L., Zhu, M.Y., 2002. A functional model of responsive suspension-feeding and growth in bivalve shellfish, configured and validated for the scallop Chlamys farreri during culture in China. J. Exp. Mar. Biol. Ecol. 281, 13-40.

Héral, M., 1993. Why carrying capacity models are useful tools for management of bivalve molluscs culture. In: Dame, R.F. (Ed.), Bivalve Filter Feeders in Estuarine and Coastal Ecosystem Processes. Springer-Verlag, Berlin, pp. 455-477.

Kooijman, S.A.L.M., 1986. Energy budgets can explain body size relations. J. Theor. Biol. 121, 269-282.

Kooijman, S.A.L.M., 2000. Dynamic energy and mass budgets in biological systems. Cambridge Univ. Press, Cambridge.

Kooijman, S.A.L.M., 2006. Pseudo-faeces production in bivalves. J. Sea Res. 56, 103-106.

Landsberg, J.H., 2002. The effects of harmful algal blooms on aquatic organisms. Reviews in Fisheries Science 10, 113-390.

Le Gall, J.L. Rallard, O., 1988. Influence of temperature on the physiology of the oyster Crassostrea gigas. Océanis 14, 603-608.

Le Moullac, G., 2008. Adaptation du métabolisme respiratoire de l'huître creuse Crassostrea gigas. PhD thesis, University of Caen, Caen, $161 \mathrm{pp}$.

Lika, K., Nisbet, R.M., 2000. A dynamic energy budget model based on partitioning of net production. J. Math. Biol. 41, 361-386.

Llewellyn, C.A., Fishwick, J.R., Blackford, J.C., 2005. Phytoplankton community assemblage in the English Channel: a comparison using chlorophyll a derived from HPLCCHEMTAX and carbon derived from microscopy cell counts. J. Plankton Res. 27, 103119.

Mao, Y., Zhou, Y., Yang, H., Wang, R., 2006. Seasonal variation in metabolism of cultured Pacific oyster, Crassostrea gigas, in Sanggou Bay, China. Aquaculture 253, 322-333. 
1 Menden-Deuer, S., Lessard, E.J., 2000. Carbon to volume relationships for dinoflagellates, diatoms, and other protist plankton. Limnol. Oceanogr. 45(3): 569-579.

Montagnes, D.J.S., Berges, J.A., Harrison, P.J., Taylor, F.J.R, 1994. Estimating carbon, nitrogen, protein, and chlorophyll $a$ from volume in marine phytoplankton. Limnol. Oceanogr. 39(5): 1044-1060.

Nisbet, R.M., Muller, E.B., Lika, K., Kooijman, S.A.L.M., 2000. From molecules to ecosystems through dynamic energy budget models. J. Anim. Ecol. 69, 913-926.

Pouvreau, S., Bourles, Y., Lefebvre, S., Gangnery, A., Alunno-Bruscia, M., 2006. Application of a dynamic energy budget model to the Pacific oyster, Crassostrea gigas, reared under various environmental conditions. J. Sea Res. 56, 156-167.

Powell, E.N., Hofmann, E.E., Klinck, J.M., Ray, S.M., 1992. Modelling oyster populations: a commentary on filtration rate: is faster always better? J. Shellfish Res. 11, 387-398.

Raillard, O., Deslous-Paoli, J.M., Héral, M., Razet, D., 1993. Modélisation du comportement nutritionnel et de la croissance de l'huître japonaise Crassostrea gigas. Oceanol. Acta 16, 73-82.

Ren, J.S., Ross, A.H., Schiel, D.R., 2000. Functional descriptions of feeding and energetics of the Pacific oyster Crassostrea gigas in New Zealand. Mar. Ecol. Prog. Ser. 208, 119-130.

Ren, J.S., Ross, A.H., 2001. A dynamic energy budget model of the Pacific oyster Crassostrea gigas. Ecol. Model. 142, 105-120.

Ren, J.S., Ross, A.H., 2005. Environmental influence on mussel growth: A dynamic energy budget model and its application to the greenshell mussel Perna canaliculus. Ecol. Model. $189,347-362$.

Ren, J.S., Schiel, D., R., 2008. A dynamic energy budget model: parameterisation and application to the Pacific oyster Crassostrea gigas in New Zealand waters. J. Exp. Mar. Biol. Ecol. 361, 42-48.

Robert, R., Parisi, G., Pastorelli, R., Poli, B.M., Tredici, M., 2002. The food quality of Tetraselmis suecica slurry for Crassostrea gigas spat. Haliotis 31, 53-56.

Ross, A.H., Nisbet, R.M., 1990. Dynamic models of growth and reproduction of the mussel Mytilus edulis L. Funct. Ecol. 4, 777-787.

Scholten, H., Smaal, A.C., 1998. Responses of Mytilus edulis L. to varying food concentrations: testing EMMY, an ecophysiological model. J. Exp. Mar. Biol. Ecol. 219, 217-239. 
Bourlès et al., submitted in Journal of Sea Research

1 Smaal, A.C., Widdows, J., 1994. The scope for growth of bivalves as an integrated response 2 parameter in biological monitoring. In: Kramer K. (Ed.), Biomonitoring of Coastal Waters and Estuaries. CRC Press, Boca Raton, pp. 247-268.

4 Strathmann, R.R., 1967. Estimating the organic carbon content of phytoplankton from cell 5

Van der Veer, H.W., Cardoso, J.F.M.F., Van der Meer, J., 2006. The estimation of DEB 10 parameters for various Northeast Atlantic bivalve species. J. Sea Res. 56, 107-124.

11 Van Haren, R.J.F., Kooijman, S.A.L.M., 1993. Application of the dynamic energy budget 12

13 Widdows, J., 1976. Physiological adaptation of Mytilus edulis to cyclic temperatures. J. comp. 14 Physiol. 105, 115-128. 


\section{Tables}

4 Table 1: DEB parameter values used as in Pouvreau et al. (2006) and values of updated

5 boundaries of the optimal temperature range for ingestion and respiration rates.

\begin{tabular}{|c|c|c|c|c|}
\hline Parameters & Symbol & Units & Value & References \\
\hline \multicolumn{5}{|l|}{ Primary parameters: } \\
\hline A rrhenius temperature & $\mathrm{T}_{\mathrm{A}}$ & K & 5800 & V an der V eer et al. (2006) \\
\hline Half saturation coefficient & $x_{k}$ & - & - & Free-fitting (cf. food quantifier) \\
\hline M ax. surface area-specific ingestion rate & $\left\{p_{x m}\right\}$ & $\mathrm{Jcm}^{-2} \mathrm{~d}^{-1}$ & 560 & V an der $V$ eer et al. (2006) \\
\hline A ssimilation efficiency & ae & - & 0.75 & V an der V eer et al. (2006) \\
\hline V olume-specific maintenance costs & {$\left[p_{m}\right]$} & $\mathrm{Jcm}^{-3} \mathrm{~d}^{-1}$ & 24 & V an der $V$ eer et al. (2006) \\
\hline M aximum storage density & {$\left[E_{M}\right]$} & $\mathrm{J} \mathrm{cm}^{-3}$ & 2295 & V an der V eer et al. (2006) \\
\hline V olume-specific costs for structure & {$\left[E_{G}\right]$} & $\mathrm{J} \mathrm{cm}^{-3}$ & 1900 & V an der V eer et al. (2006) \\
\hline Structural volume at sexual maturity & $V p$ & $\mathrm{~cm}^{-3}$ & 0.4 & Pers. unpubl. data \\
\hline Fraction of $p_{c}$ spent on maintenance plus growth & $\kappa$ & - & 0.45 & V an der $V$ eer et al. (2006) \\
\hline Fraction of reproduction energy fixed in eggs & $\kappa_{R}$ & - & 0.7 & Pouvreau et al. (2006) \\
\hline Shape coefficient & $\delta_{\mathrm{M}}$ & - & 0.175 & V an der V eer et al. (2006) \\
\hline \multicolumn{5}{|l|}{ A dditional parameters: } \\
\hline Lower boundary of tolerance range & $T_{L}$ & K & 281 & V an der V eer et al. (2006) \\
\hline Upper boundary of tolerance range & $\mathrm{T}_{\mathrm{H}}$ & K & 305 & V an der $V$ eer et al. (2006) \\
\hline Rate of decrease at lower boundary & $\mathrm{T}_{\mathrm{AL}}$ & K & 75000 & V an der V eer et al. (2006) \\
\hline Rate of decrease at upper boundary & $\mathrm{T}_{\mathrm{AH}}$ & K & 30000 & V an der V eer et al. (2006) \\
\hline Energy content of reserves (in ash free dry mass) & $\mu_{\mathrm{E}}$ & $\mathrm{J} \mathrm{mg}^{-1}$ & 17.5 & Deslous-Paoli and Héral (1988) \\
\hline Gonado-somatic index triggering spawning & GI & $\%$ & 40 & Pers. unpubl. data \\
\hline Temperature threshold triggering spawning & $T_{S}$ & ${ }^{\circ} \mathrm{C}$ & 22 & Pers. unpubl. data \\
\hline \multicolumn{5}{|l|}{$\begin{array}{l}\text { New boundary values of the optimal temperature } \\
\text { range: }\end{array}$} \\
\hline Lower boundary of tolerance range & $T_{L}$ & K & 276 & This study \\
\hline Upper boundary of tolerance range for ingestion & $\mathrm{T}_{\mathrm{H} \text { ing }}$ & K & 298 & This study \\
\hline Upper boundary of tolerance range for respiration & $T_{H}$ resp & K & 305 & This study \\
\hline
\end{tabular}


B ourlès et al., submitted in J ournal of Sea Research

1

2 Table 2.A: M ost abundant phytoplankton species identified in the oyster pond from J anuary

32006 to January 2007 in terms of cell number, percentage of the total phytoplankton

4 enumeration, bloom values and their seasonality.

\begin{tabular}{lrccc}
\hline Species or group & $\begin{array}{c}\text { Cumulative } \\
\text { cell number }\end{array}$ & $\begin{array}{c}\text { \% of total } \\
\text { enumeration }\end{array}$ & $\begin{array}{c}\text { M aximum } \\
\text { bloom(s) in cell L }\end{array}$ & $\begin{array}{c}\text { Date } \\
(2006)\end{array}$ \\
\hline Tetraselmis sp. & 5233600 & $\mathbf{2 6 . 9}$ & 4869000 & 6 September \\
Euglenophyceae (Class) & 3953400 & $\mathbf{2 0 . 3}$ & 3628400 & 6 July \\
Nano-flagellates & 2775200 & $\mathbf{1 4 . 3}$ & 2143800 & 1 J une \\
Chaetocer os spp. & 2067600 & $\mathbf{1 0 . 6}$ & 1662000 & 22 J une \\
Nitzschia longissima & 1492600 & $\mathbf{7 . 7}$ & $627600 / 154000$ & 20 A pril / 16 M ay \\
Kryptoperidinium foliaceum & 1119400 & $\mathbf{5 . 8}$ & $511000 / 436000$ & $20 / 29$ September \\
Skeletonema costatum & 636000 & $\mathbf{3 . 3}$ & $55800 / 73200$ & 14 February / 2 M arch \\
Total phytoplankton cells & $\mathbf{1 9 4 5 2 6 0 0}$ & & $114000 / 216800$ & $16 / 30$ M arch \\
\hline
\end{tabular}

8 Table 2.B: Phytoplankton with the greatest contribution in terms of cumulative cell volume

9 estimated in the oyster pond between January 2006 and January 2007 from size and mean

10 volume (N. Guillocheau, 1988; laboratory measurements in this study). The percentage of the

11 cumulative cell volume is calculated according the total cumulative cell volume.

\begin{tabular}{|c|c|c|c|c|}
\hline Species or group & $\begin{array}{l}\text { Size in } \mu \mathrm{m} \\
\text { (minimum; } \\
\text { maximum) }\end{array}$ & $\begin{array}{c}\text { Mean } \\
\text { biovolume } \\
\left(\mu \mathrm{m}^{3} \mathrm{cell}^{-1}\right)\end{array}$ & $\begin{array}{c}\text { Cumulative cell } \\
\text { biovolume } \\
\left(10^{6} \mu \mathrm{m}^{3}\right)\end{array}$ & $\begin{array}{c}\% \text { of total } \\
\text { volume }\end{array}$ \\
\hline Kryptoperidinium foliaceum & $28 \times 25 ; 53 \times 51$ & 30000 & 33582 & 27.5 \\
\hline Pleurosigma elongatum & $190 \times 15 ; 205 \times 20$ & 150000 & 30990 & 25.4 \\
\hline Euglenophyceae (Class) & $24 \times 8 ; 50 \times 15$ & 3000 & 11860 & 9.7 \\
\hline Pleurosigma + Gyrosigma spp. & $53 \times 13 ; 700 \times 38$ & 200000 & 10160 & 8.3 \\
\hline Entomoneis spp. & $100 \times 40 ; 100 \times 55$ & 50000 & 8680 & 7.1 \\
\hline Flavella sp. & $180 \times 72 ; 196 \times 78$ & 600000 & 3240 & 2.7 \\
\hline $\begin{array}{l}\text { Tetraselmis sp. } \\
\text { Total cell volume }\end{array}$ & $8 \times 6 ; 13 \times 9$ & $\begin{array}{r}500 \\
6200 \\
\end{array}$ & $\begin{array}{r}2617 \\
122133\end{array}$ & 2.1 \\
\hline
\end{tabular}

12

13

14

15 
B ourlès et al., submitted in J ournal of Sea Research

2 Table 3: Ordinary least square regression of observed against modelled dry flesh mass of $C$. 3 gigas for the seven simulations carried out with each food quantifier, i.e. Chl-a (chlorophyll 4 a), POC (particulate organic carbon), POM (particulate organic matter), phyto 5 (phytoplankton), S-phyto (selected phytoplankton). Both phyto and S-phyto are expressed in 6 terms of cell number or cumulative biovolume. $\mathrm{R}^{2}$, coefficient of determination and 7 corresponding p-value on null hypothesis. Slope and intercept values are given for each 8 regression model, with corresponding $p$-values of testing slopes different from 1 and intercept 9 different from 0.

\begin{tabular}{|c|c|c|c|c|c|c|c|}
\hline $\begin{array}{l}\text { Regression } \\
\text { parameters }\end{array}$ & Chl-a & POC & POM & $\begin{array}{c}\text { Phyto } \\
\text { (in number) }\end{array}$ & $\begin{array}{c}\text { Phyto } \\
\text { (in volume) }\end{array}$ & $\begin{array}{c}\text { S-phyto } \\
\text { (in number) }\end{array}$ & $\begin{array}{l}\text { S-phyto } \\
\text { (in volume) }\end{array}$ \\
\hline$R^{2}$ & 0.767 & 0.754 & 0.739 & 0.688 & 0.572 & 0.865 & 0.669 \\
\hline ( $p$-value) & $\left(1.92 \cdot 10^{-6}\right)$ & $\left(3.85 \cdot 10^{-6}\right)$ & $\left(4.85 \cdot 10^{-6}\right)$ & $\left(2.07 \cdot 10^{-5}\right)$ & $\left(2.81 \cdot 10^{-4}\right)$ & $\left(2.25 \cdot 10^{-8}\right)$ & $\left(3.39 \cdot 10^{-5}\right)$ \\
\hline Slope & 0.796 & 0.868 & 0.967 & 1.201 & 0.794 & 1.008 & 1.091 \\
\hline (p-value) & $(0.082)$ & $(0.311)$ & $(0.822)$ & $(0.335)$ & $(0.249)$ & $(0.940)$ & $(0.642)$ \\
\hline Intercept & 0.035 & -0.026 & -0.092 & -0.261 & -0.112 & -0.002 & -0.193 \\
\hline (p-value) & $(0.880)$ & $(0.920)$ & $(0.761)$ & $(0.539)$ & $(0.756)$ & $(0.991)$ & $(0.631)$ \\
\hline
\end{tabular}

10

11

12

13 


\section{$1 \quad$ Figures}

3 Figure 1: The two different A rrhenius relationships estimated for $\mathrm{C}$ rassostrea gigas ingestion 4 rate (grey line) and respiration rate (black line). A rrhenius corrections are given for 5 temperatures from $3^{\circ} \mathrm{C}$ to $32^{\circ} \mathrm{C}$. Data from Le Gall and Raillard, 1988; B ougrier et al., 1995; 6 Ren and Ross, 2000; M ao et al., 2006; and Le M oullac 2008.

Figure 2: (A) M arennes-Oléron Bay and the location of the experimental study site. (B) The experimental study site showing the channel system and the oyster ponds.

Figure 3: The first forcing variable of the model: seawater temperature monitored in the oyster pond from J anuary 2006 to J anuary 2007 , varying from $3^{\circ} \mathrm{C}$ in J anuary 2006 to $30^{\circ} \mathrm{C}$ in July 2006.

Figure 4: The second forcing variable of the model: food density illustrated through different food quantifiers monitored in the oyster pond from J anuary 2006 to January 2007: POC (A), POM (B), chl-a (C) and phytoplankton enumeration (D) expressed in cell number per litre (black line) and in cumulative cell biovolume $\left(\mu \mathrm{m}^{3} \mathrm{~L}^{-1}\right.$, grey line). Symbols 1,2 and 3 indicate common peaks identified in chl-a, POC and POM, whereas symbols from $\mathrm{i}$ to viii indicate peaks which were not identified in all of the food quantifiers.

Figure 5: Comparisons between observed (symbols, with bars for standard deviation) and simulated (solid dark line) dry flesh mass, from January 2006 to J anuary 2007, for different food quantifiers: (A) shows the simulation obtained with POC, (B) with the POM, and (C) with the chl-a.

Figure 6: Comparisons between observed (symbols, with bars for standard deviation) and simulated (solid dark line) dry flesh mass, from January 2006 to January 2007, with phytoplankton enumeration used as a food quantifier: (A) and (B) show the simulations obtained using selected phytoplankton composition expressed in number and volume, expressed in number and volume, respectively. 
B ourlès et al., submitted in J ournal of Sea Research

1

2 Figure 1:

3

4

5

6

7

8

9

10

11

12

13

14

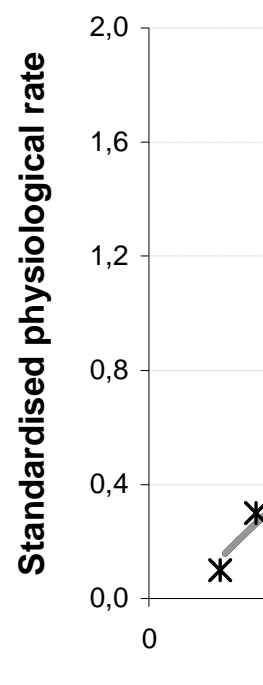

15

16

17

18 
B ourlès et al., submitted in J ournal of Sea Research

2 Figure 2:

3

4

5

6

7

8

9

10

11

12

13

14

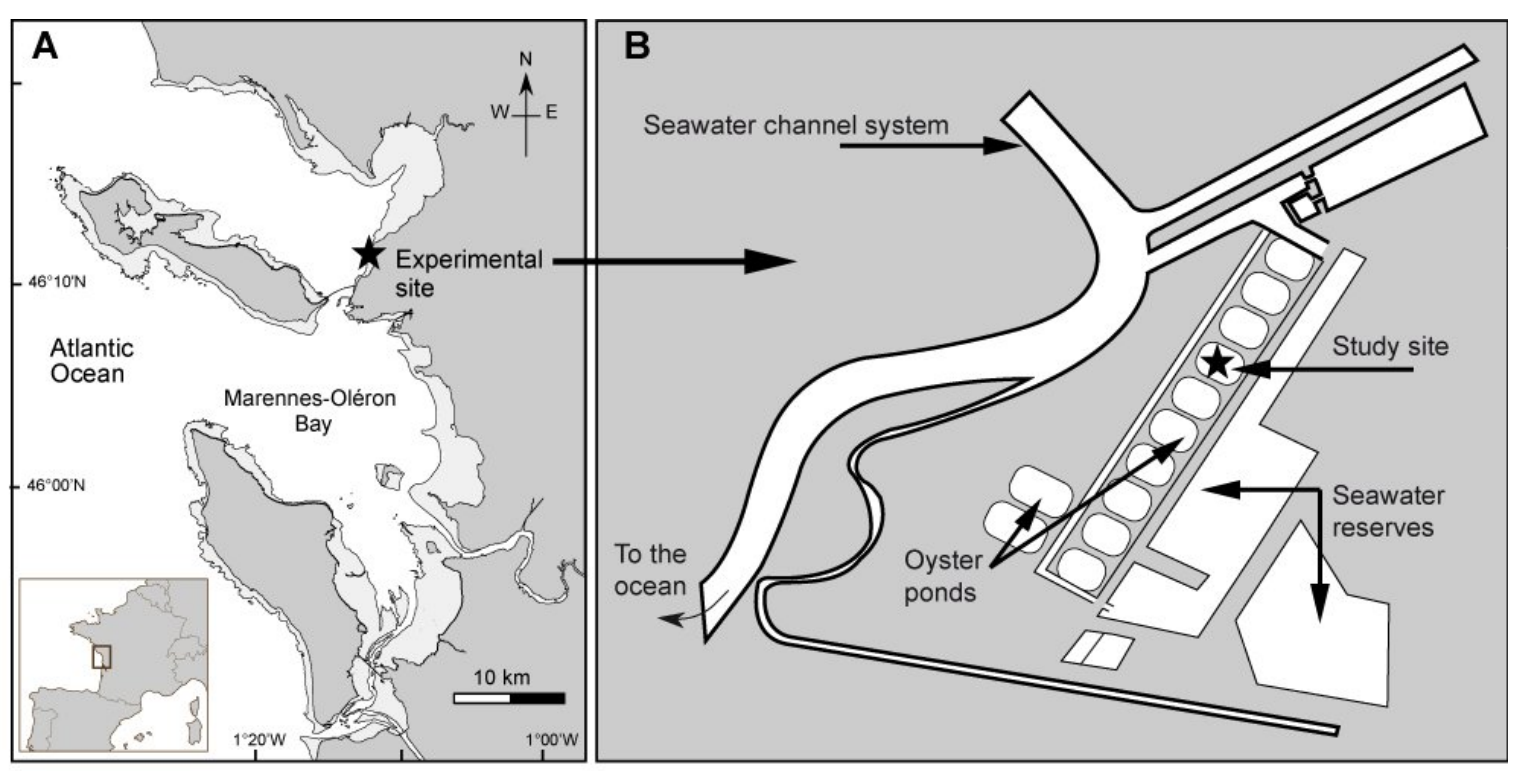

15

16

17

18

19 
B ourlès et al., submitted in J ournal of Sea Research

1

2 Figure 3 :

3

4

5

6

7

8

9

10

11

12

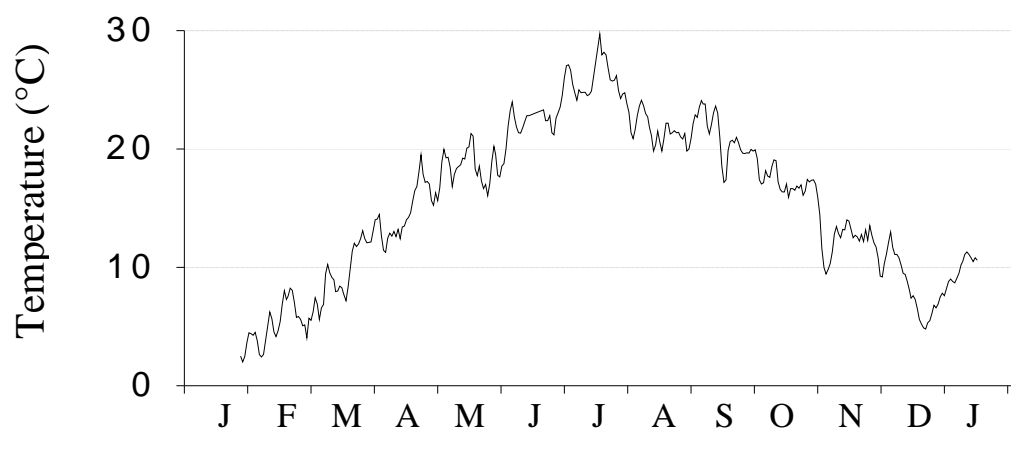

Time (months)

13

14

15 
B ourlès et al., submitted in J ournal of Sea Research

2 Figure 4:

3

4

5

6

7

8

9

10

11

12

13

14

15

16

17

18

19

20

21

22

23

24

25

26

27

28

29

30

31

(A)

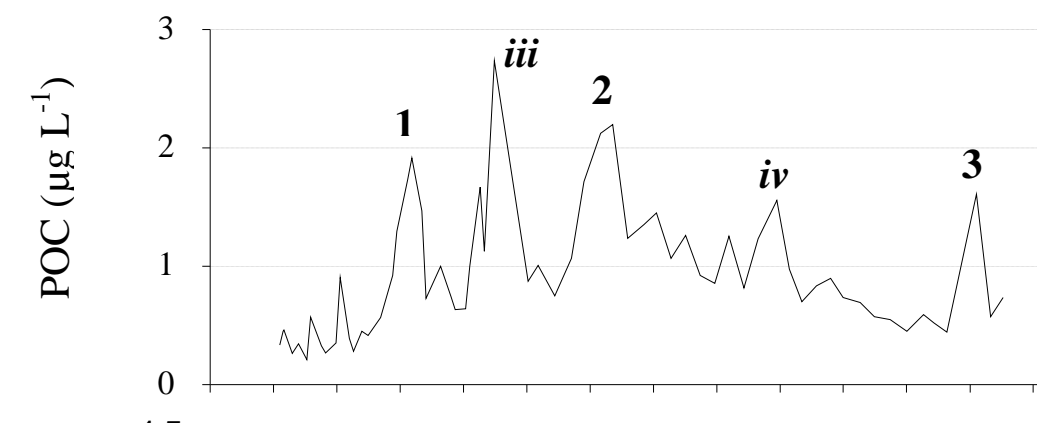

(B)

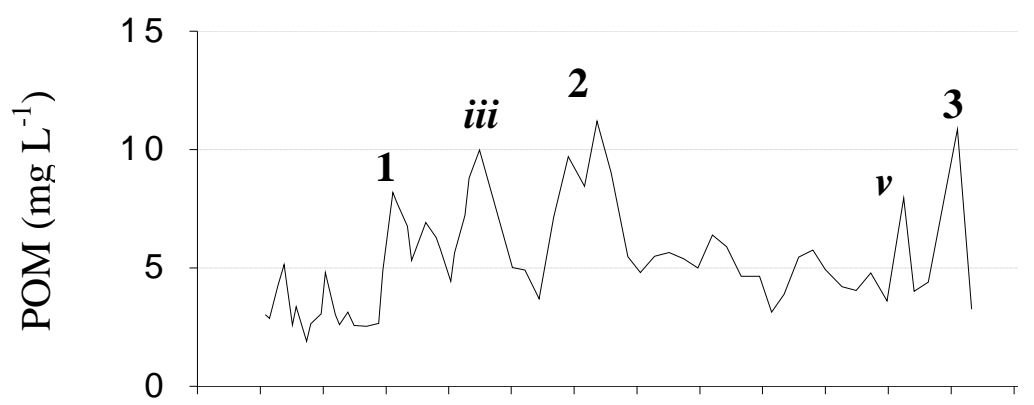

(C)

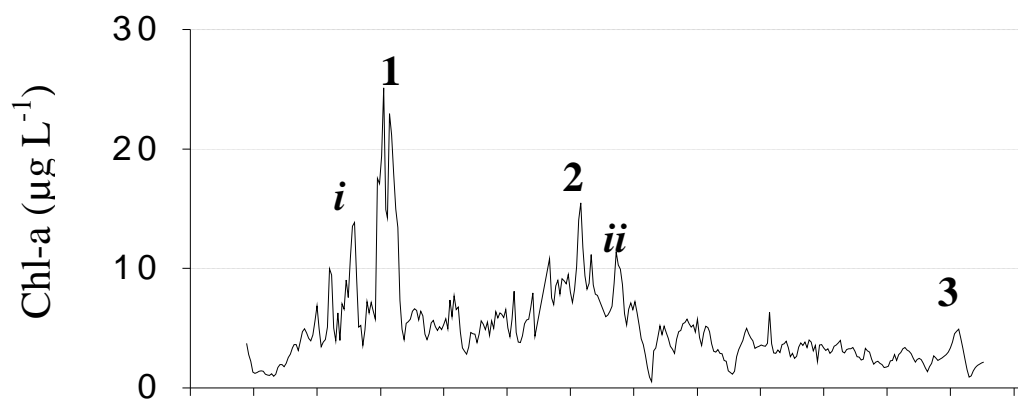

(D)
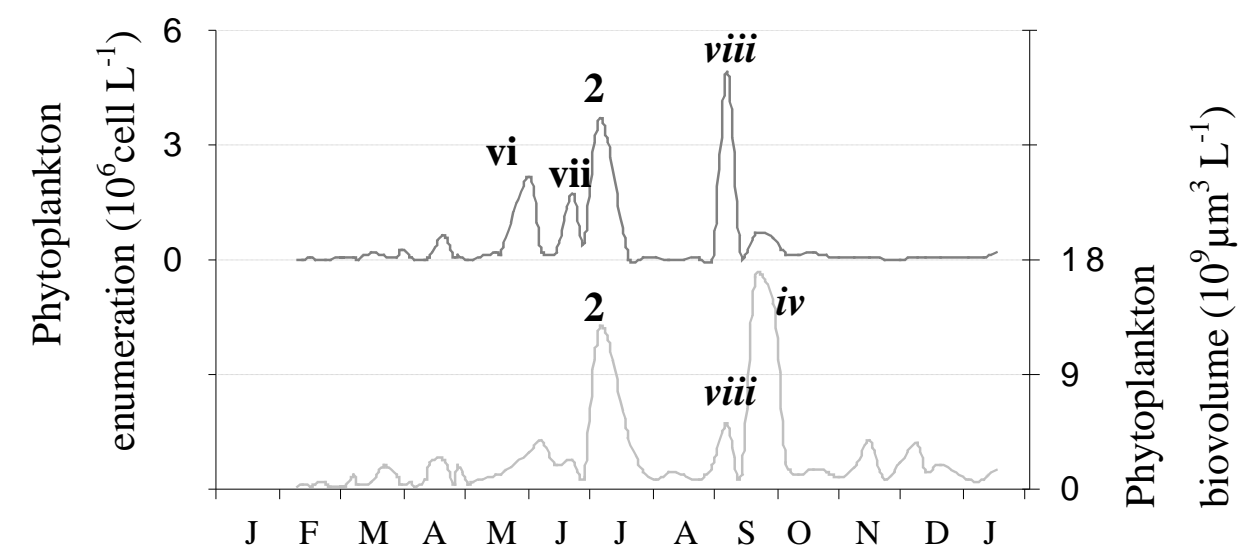

Time (months) 
B ourlès et al., submitted in J ournal of Sea Research

1

2 Figure 5:

3

4

5

6

7

8

9

10

11

12

13

14

15

16

17

18

19

20

21

22

23

24

25

26

27

28

29

30
(A)

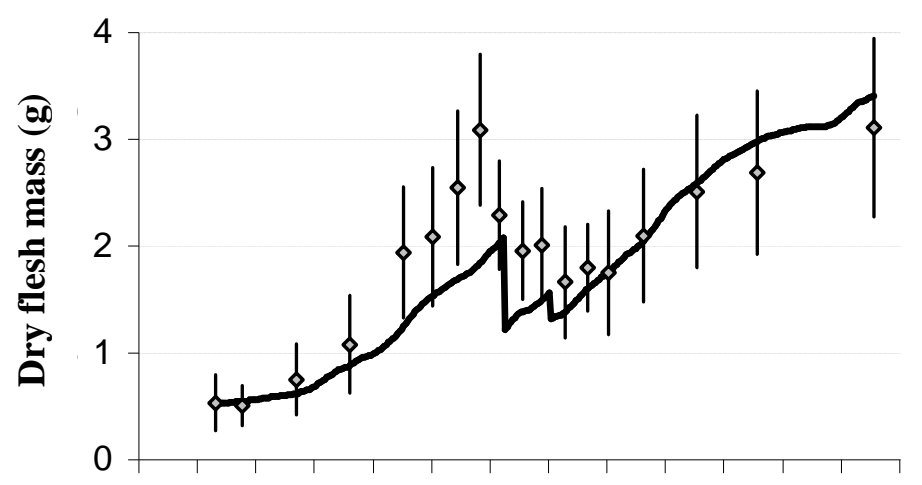

(B)

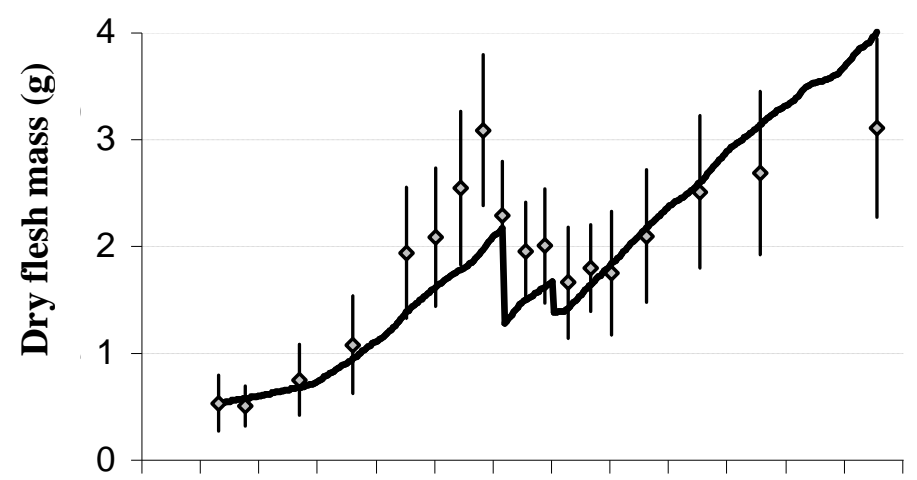

(C)

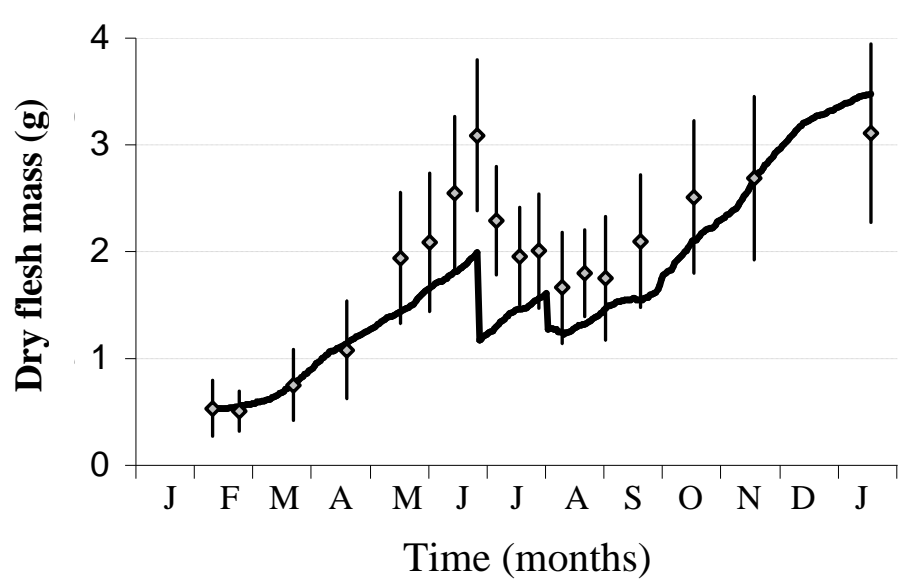


B ourlès et al., submitted in J ournal of Sea Research

1

2 Figure 6:

3

4

5

6

7

8

9

10

11

12

13

14

15

16

17

18

19

20

21

22

23

24

25

26

27

28

29

30

31

32

33

34
(A)

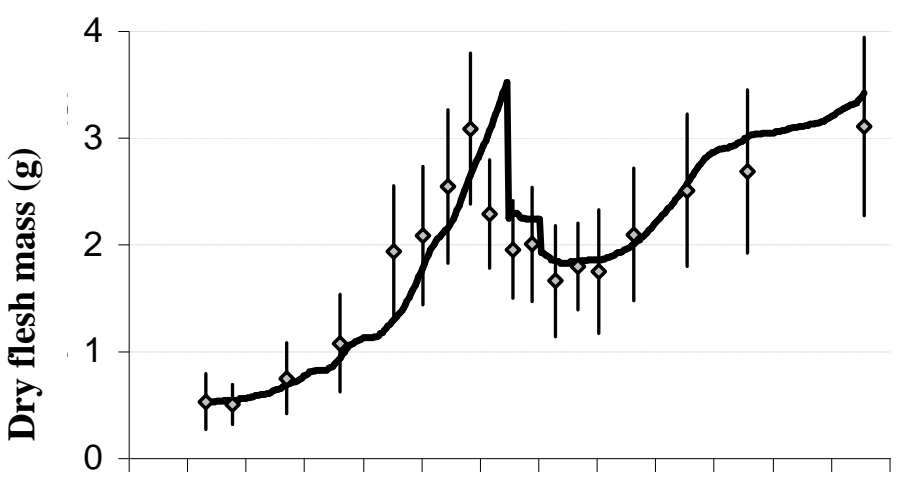

(B)

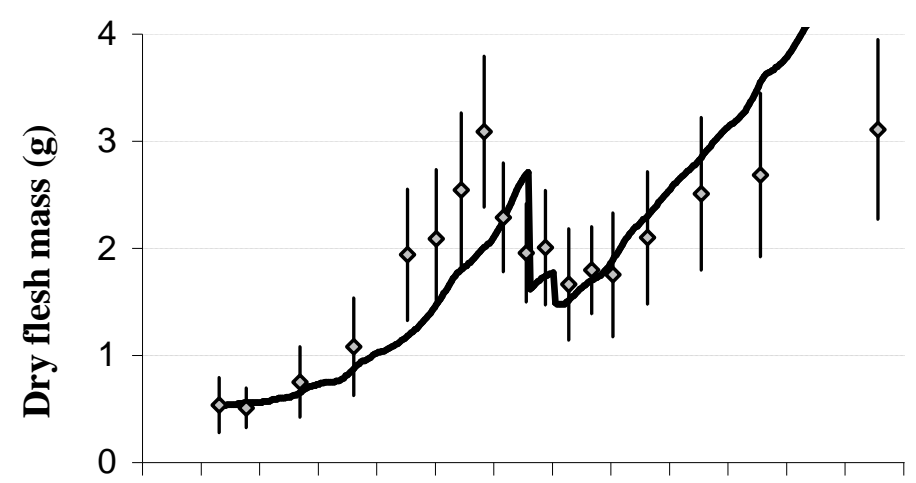

(C)

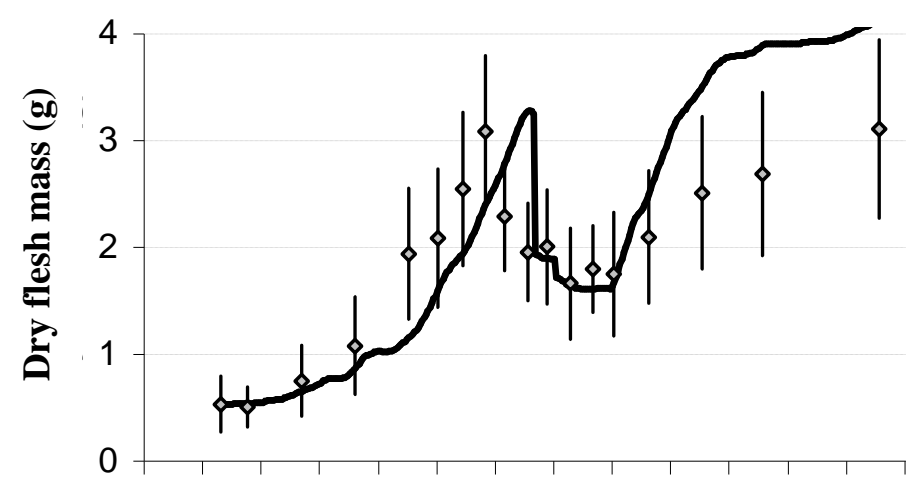

(D)

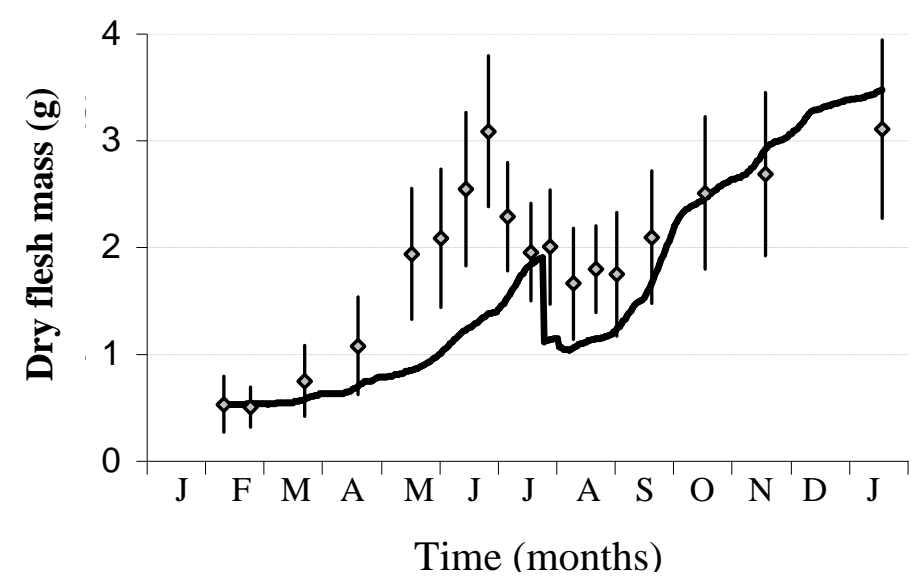

